The following Chapters, 13 to 21, reproduce this same plan for the eighteenth century. Thus, new people were successfully integrated into the empire (Chapter 13), while the army and the administration were reformed (Chapter 14). Reforms were informed by enlightenment ideas, combining the German enlightenment's emphasis on orderliness and duty with the French preoccupation with rational thinking. Yet the state perpetuated a centralized bureaucratic network in order to accomplish the fundamental tasks of revenue collection, military recruitment, and local control (Chapter 15). Russia became more intentional and effective in exerting empire-wide control, particularly in the second half of the eighteenth century. The main weakness of this system was the lack of any proper state budget and, thus, the increasing state deficit. In this context, surveillance and control intervened to counterbalance instability and economic difficulties (Chapter 16). Social mobility was certainly limited by the soslovie system, even if it was much more flexible than conventionally argued (Chapters 17 and 18). Again, Orthodoxy remained the state religion; even if the enlightenment encouraged Russian educated society to accept religious diversity: anxieties, in particular with Islam, were tangible (Chapters 19, 20). Despite its diversity, the Russian nobility also relied upon serfdom and was proud of the empire and their autocrat (Chapter 21).

Kollmann concludes that early modern Russia did not develop any sort of national consciousness comparable to that emerging in western Europe. Eighteenthcentury attitudes towards the subject people were not perceived as Russification but as enlightenment. Only with rising nationalism in the nineteenth century did the imperial center attempted to impose the "Russian way" on the whole empire.

This otherwise excellent book has two minor drawbacks: first, the chronology adopted (1450-1801) is not justified and recalls Russian nationalistic approaches, putting the war against Kazan', for example, as the rise of the Russian power. The second concerns the bibliography: except for two to three titles among hundreds, exclusively Anglo-American texts are used, as if Germans, the French, and above all, Russians had never published on these topics. The politics of difference was eventually relevant in autocratic Russia, but it has not yet entered academia.

ALESSANDRO STANZIANI EHESS-PSL-CNRS, Paris

\title{
Lost Kingdom: The Quest for Empire and the Making of the Russian Nation from 1470 to the Present. By Serhii Plokhy. New York: Basic Books, 2017. xxvi, 398 pp. Appendix. Notes. Index. Bibliography. Maps. \$32.00, hard bound. doi: 10.1017/slr.2018.251
}

What kind of a nation is Russia? What does it mean to call it an "imperial nation"? Does it continue to have a hankering for empire, despite the break-up of the Soviet Union? What in particular is the significance of the legacy of the "lost kingdom" of Kyivan/Kievan Rus'-the adjoining territories of the East Slavs, including Russia, Ukraine, and Belarus, which from the seventeenth century came to be designated as a tripartite unity of "Great," "Little," and "White” Russia (and including, on occasion, an additional component, the Ruthenians of Galicia, as "Red Rus'”)? This is the grand subject of Serhii Plokhy's fascinating and constantly stimulating inquiry into the historical origins of what is still very much an ongoing issue, indeed a matter of life and death for many thousands. The book, he says, was inspired by the still-unresolved Russo-Ukrainian war of 2014, though it draws upon and continues the investigation begun in his earlier works, especially The Origins of the Slavic Nations: Premodern 
Identities in Russia, Ukraine, and Belarus (2006) and The Last Empire: The Final Days of the Soviet Union (2014).

The historical narrative is in one sense familiar, beginning in the west with the "gathering of the lands of Rus'" (18) through Ivan III's conquest of Novgorod in 1471, continuing with Ivan IV's conquest of Kazan' and Astrakhan, the claims to be the successors to the Golden Horde in the east, the accession of the Ukrainian Cossack Hetmanate of Bohdan Khmelnytskii to the Russian Empire in 1654, Russia's reacquisition of large parts of the historic Rus' in the three eighteenth-century partitions of Poland, and the fitful attempts at Russification of the western borderlands in the nineteenth century. The Soviet Union-paradoxically, given its theoretical commitment to internationalism -through the policies of korenizatsiia (indigenization) actually gave the three parts of Kyivan Rus' more definition as separate nations, particularly in the case of Ukraine, though it is questionable that "almost by default, Lenin became the father of the modern Russian nation, while the Soviet Union became its cradle" (225). As late as the break-up of the Soviet Union, as Plokhy himself shows, the character of the Russian nation, and the meaning of Russian nationalism, was in doubt, sometimes taking a narrowly ethnic form, sometimes reverting to the more expansive, "Big Russia” model.

This is not, however, in any sense a conventional history of the Russian Empire and its successor, the Soviet Union. This is why it will not replace, nor is it intended to, excellent one-volume histories such as Geoffrey Hosking's Russia: People and Empire, 1552-1917 (1998), and Andreas Kappeler's The Russian Empire: A Multi-Ethnic History (2001). These all have their distinctive approaches, as does the recent volume by Valerie A. Kivelson and Ronald Grigor Suny, Russia's Empires (2017). What Plokhy valuably offers, more unusually, is a view of Russia from the margins, from the western borderlands. Though the focus is still Moscow and St. Petersburg, tsarist and communist, we learn as much about Ukrainian (and, to a lesser extent, Belarusian) thinking and writing-philosophical, philological, historiographical-as we do about policy-makers and their advisers in the imperial capitals. Nor is this in the spirit of Ukrainian victimhood, still less of Ukrainian nationalism. Plokhy is even-handed throughout, laying out the debates and disagreements clearly and fairly. Only at the very end, when he discusses Russian action in Ukraine after 2014, does the concern, and the feeling, show through.

He concludes that whatever the final outcome of that conflict, "the imperial construct of a big Russian nation is gone, and no restoration project can bring it back to life" (346). Can one really be that confident? There seem to be plenty of thinkers around in Russia these days who have certainly not given up on Greater Russia. Plokhy himself quotes Putin's justification for the annexation of Crimea, as well as for other Russian claims in Ukraine: "We are one people . . . because we have the same Kyivan baptismal font in the Dnieper" (340). Part of the difficulty of accepting Plokhy's conclusion has to do with the way he slips between several different definitions of the Russian nation, so that, for instance, Peter and Catherine are credited with having created the "Russian imperial nation" (69), Sergei Uvarov and Nicholas II are seen as engaged in the attempt "to link empire and nationality" (84), and the Russian Empire is said as having by 1914 "fully succeeded in making the transition to a Russian nation-state" (185). There is much ambiguity here: it is almost as if "nation" and "empire" can be equated. Normally, that is not taken to be the case; but perhaps it is precisely what Putin has in mind in his conception of the Russian nation.

KRISHAN KUMAR University of Virginia 